\title{
Modelling Antagonic Effect of Lactic Acid Bacteria Supernatants on Some Pathogenic Bacteria
}

\author{
Augustus Caeser Franke Portella ${ }^{1}$, Susan Karp ${ }^{1}$, Gessiel Newton Scheidt ${ }^{1}$, Adenise Lorenci \\ Woiciechwski $^{1}$, Jose Luis Parada ${ }^{2}$ and Carlos Ricardo Soccol ${ }^{1 *}$ \\ ${ }^{1}$ Departamento de Bioprocessos e Biotecnologia; Universidade Federal do Paraná; C.P.: 19011; 81531-970; \\ Curitiba - PR - Brasil. ${ }^{2}$ Departamento de Fitotecnia e Fitosanidade; Universidade Federal do Paraná; C.P.:19061; \\ 81531-990; Curitiba - PR - Brasil
}

\begin{abstract}
This work presents a statistical model of survival analysis for three pathogenic bacterial strains (Escherichia coli, Listeria monocytogenes and Staphylococcus aureus), when treated with neutralized and non-neutralized filtered supernatants broth from cultures of Lactobacillus acidhophilus, Lactobacillus rhamnosus and Lactobacillus sake. Survival analysis is a method employed to determine the period of time from an initial stage up to the occurrence of a particular event of interest, as death or a particular culture growth failure. In order to evaluate the potential efficacy of the ahead mentioned lactic acid bacteria when used as bioprotective starters in foods, experimental data were statistically treated and expressed by simple representative curves. Following the methodology of Cox and Kaplan-Meier, it was possible to make the selection of the best bioprotective lactic starter, as a predictive tool for evaluation of shelf life and prevention of eventual risks in fresh sausages and other similar food products.
\end{abstract}

Keywords: Statistical model, survival analysis, bioprotection

\section{INTRODUCTION}

Biopreservation has received increased attention as a good alternative to extend shelf-life and promote microbiological food safety. Bioprotective microbial starters are used to improve the quality of fresh sausages and other similar foods under conditions of stored and low temperatures. The activity of these cultures is based on nutrient competition and/or production of low $\mathrm{pH}$ and antimicrobial compounds such as organic acids (lactic and acetic), hydrogen peroxide, antimicrobial compounds as reuterin and some specific bacteriocins (Parada et al., 2007; Klaenhammer, 2001). Fresh sausages are elaborated with grounded raw meat, mixed with sugar, spices and additives, and filled in artificial or natural casings. Non-cooked sausages, with a $\mathrm{pH}$ value of about 5.5 and water activity $\left(A_{w}\right)$ equal to or higher than 0.97 , are highly perishable products (Cocolin et al., 2004).

Fresh sausages in Brazil and other countries are usually packaged in normal or modified atmosphere and stored at $4{ }^{\circ} \mathrm{C}$ for a maximum period of 10 days. In tropical countries, the temperature of refrigeration is usually higher and the product is frequently submitted to non suitable temperatures and, as a consequence, the period of safe conservation is reduced. The shelf life of fresh sausages and other fresh products is dependent on

*Author for correspondence: soccol@ufpr.br 
the initial number of contaminant microflora and the temperature of conservation. The risk of a disease burst is also dependent on these variables.

The use of GRAS (Generally Regarded as Safe) bioprotective lactic acid microorganisms in meat processing has various purposes (Al-Nabulsi and Holley, 2007), such as safety improvement by inactivation of pathogens (Caplice and Fitzgerald, 1999), $\mathrm{pH}$ reduction, thus increasing stability of the product and extending the shelf life by inhibition of undesirable spoilage microorganisms (Cocolin et al., 2004). Lactic acid starters provide diversity in products by modification of raw materials, resulting in new sensorial properties and production of health benefits by the probiotic effects associated to their presence (Lücke, 2000).

Microbial growth evolution in food has been studied based on statistical models and laws of probability (Koutsoumanis and Sofos, 2005; Baranyi and Roberts, 1994), under different physical and chemical conditions, as temperature, $A_{w}, \mathrm{pH}$, and type of culture, among others. Survival analysis is a predictive method employed to determine the period of time from an initial stage until the occurrence of a particular event of interest, as death, or a particular failure.

Many applications of survival analysis are known in medical research, for example, the period of time that patients survive after a diagnostic of a certain illness (Crowley and Breslow, 1994; Ederer et al., 1961). It requires a well-defined origin, an appropriate scale for measuring the period of time and an unambiguous definition of failure. Parametric survival analysis aims to determine the optimal parameters of a fixed distribution describing the time of failure as a function of probability.

Another function of interest in survival analysis is the hazard function, given by the instantaneous probability of failure at any time. The hazard function describes the concept of the risk of an outcome (e.g. death, failure) in an interval period after a time (t), depending on the external condition. It is the probability that an organism dies or survives somewhere between an initial time (t) and $(t+\Delta t)$, divided by the probability of surviving beyond time $(\mathrm{t})$. The hazard function seems to be a more intuitive tool used for survival analysis than the probability of density function (Lee, 1992), because it determines the instantaneous risk when an event takes place at a given time $(\mathrm{t})$.
In survival models, the response of failure time could be affected by latent variables, which may be influenced by media composition, physical conditions or co-variables, not always included in the study (Crowley and Breslow, 1994). In many and different applications of survival analysis it is difficult to observe the failure fact. Trials where failure is not observed after a considered period of time are said to be "censured".

The definition of the concept of failure time is essential to establish the "breakpoint" from which it will be measured. If, for example, we need to know the shelf life period of a product (for example, fresh sausage), it is necessary to know the date of elaboration and the time during which it is considered a safe product. It is required to collect data up to the end of the period. The occurrence of a pre-specified event is referred to as failure, and the period to appear is considered the time of failure. Those microorganisms that show no flaws have a censured time, which is the period observed since the beginning of the trial up to the end (Työppönen et al., 2003).

In most microbiological studies, there is a reasonable correlation between the time of survival and the number of microorganisms. This correlation may be modified by different factors, as microbial antagonism and environmental factors such as bacteriocins, $\mathrm{pH}$, redox potential, antioxidant compounds etc. (Vermeiren et al., 2004; Carvalho et al., 2005).

Even when the failure time is unknown, censured data should be considered in order to know the complete survival distribution, including the period of time in which the failure is not observed (Nissen and Holck 1998).

Another model employed was the estimator nonparametric method of Kaplan-Meier (Kaplan and Meier, 1958; Lee, 1992; Kleinbaum, 1995), also known as estimator product limit, proposed by these authors in 1958. This approach is widely used to estimate the function of survival in biological experiments. To obtain information, it is necessary to consider failures at different intervals of time. The nonparametric methodology of Kaplan-Meier uses the concept of independent events and conditional probability in relation with the behavior of the organism.

Lactic acid bacteria starters have demonstrated to have antagonistic effects against some pathogenic strains and spoilage microorganisms (Vermeiren et al., 2004; Lücke, 2000, Sanada et al., 2009). 
Bacteriocins are small peptides able to inhibit the growth of several undesirable bacteria that grow in foods, as Staphylococcus aureus, Listeria monocytogenes, etc. (Tagg et al., 1976). The use of bacteriocin producing strains as protective cultures for in situ control of food pathogens has shown to be useful in cheese and other foods (Holzapfel et al., 1995; Stiles, 1996; Caplice and Fitzgerald, 1999, Yamagushi et al., 2009).

The objective of this work was to use a parametric and nonparametric statistical model of survival analysis to evaluate the bioprotective action of lactic acid bacteria sterile supernatants. Three independent pathogenic cultures (Escherichia coli, Listeria monocytogenes, and Staphylococcus aureus) were treated with neutralized and nonneutralized filtered supernatants broth from cultures of Lactobacillus acidophilus, Lactobacillus rhamnosus, and Lactobacillus sake grown in MRS broth (Rogosa and Sharpe, 1961), in order to determine the most effective starter to be used in fresh sausage production.

\section{MATERIAL AND METHODS}

\section{Strains}

Different inoculum size varying from 1 to $5 \mathrm{ml}$ was tested for the effect of inoculum size on supernatants production (Ramadas, et al., 2009) and three different species of Lactobacillus were obtained from the American Type Culture Collection (ATCC) and from the Department of Bioprocess Engineering and Biotechnology (DEBB), Federal University of Paraná. These strains were tested and used as antimicrobial producing starters. Lactobacillus acidophilus (ATCC 4356), Lactobacillus sake (ATCC 15521) and Lactobacillus rhamnosus (DEEB $\mathrm{H}-19)$, stored in liquid nitrogen $\left(\mathrm{N}_{2}\right)$ at $196^{\circ} \mathrm{C}$, were reactivated in MRS broth and grown at $37^{\circ} \mathrm{C}$ during $24 \mathrm{~h}$. As testing strains, the pathogens Listeria monocytogenes (ATCC 15313), Escherichia coli (ATCC 25922) and Staphylococcus aureus (ATCC 25923) were used, and maintained at $4{ }^{\circ} \mathrm{C}$ in MRS broth. For longterm conservation, cells were centrifuged at 4,000 $\mathrm{g}$ for $15 \mathrm{~min}$, resuspended in glycerol $10 \%$, transferred to sterile microvials and kept in liquid $\mathrm{N}_{2}$ at a temperature of $-196^{\circ} \mathrm{C}$.

Supernatants obtained from lactic acid bacteria Lactobacillus strains were grown in MRS broth for $48 \mathrm{~h}$ and centrifuged at $4000 \mathrm{~g}$ for $15 \mathrm{~min}$. It was supposed that supernatants contained lactic and other acidic metabolites, bacteriocins and bacteriocin like substances. The supernatants were divided in two aliquots. One aliquot was filtrated with a sterile membrane of cellulose ester (Millipore, $0.22 \mu \mathrm{m}$-pore) and named the "nonneutralized filtrate". The other portion had the $\mathrm{pH}$ adjusted to 6.0 with $\mathrm{NaOH} 1 \mathrm{~N}$, was filtrated through $0.22 \mu \mathrm{m}$ membrane and collected in a sterile tube. This was named "neutralized filtrate".

\section{Effect of Lactobacillus supernatants on pathogenic bacteria}

For the present survival analysis study, the sterile supernatants were tested on pathogenic microorganisms (L. monocytogenes, E. coli and $S$. aureus) using ELISA microplates. The absorbance values at $\mathrm{OD}_{660}$ were recorded at $37^{\circ} \mathrm{C}$ every $2 \mathrm{~h}$ in an ELISA equipment (BioTek "Power Wave XS") using the KC Junior program. The supernatants $(90 \mu \mathrm{L})$ were added to an equal amount of MuellerHinton (MH) broth and inoculated with $20 \mu \mathrm{L}$ of the respective overnight culture of pathogens, grown in $\mathrm{MH}$ broth diluted 1:10 with sterile distilled water. All individual data were pooled and statistically treated to construct survival curves. The failure or inhibition was determined by Equation 1:

$$
F(\%)=\left(\frac{\text { Inc ODcontrot Inc ODsample }}{\text { Inc ODcontrol }}\right) \times 100
$$

Where: $F(\%)=$ percentage of inhibition of the sample in relation to the control;

Inc. OD Control = Increment in optical density of the control;

Inc. OD Sample $=$ Increment in optical density of the sample.

\section{Statistical analysis}

The growth of the pathogenic microorganisms was evaluated during $24 \mathrm{~h}$. The dependent variable was the time at the first observation of pathogenic microorganism failure (survival time T). Another property of the dataset was the presence of censored data. The variable time could have two different meanings depending on the situation: when pathogenic failure was observed, it gave the actual survival time, but for supernatants without pathogenic failure, it gave the duration of the observation period. An incomplete observation was called censored (censor $=1$ when pathogenic 
failure has happened during the observation time, otherwise censor $=0$ ). The possible presence of incomplete data cannot be accounted for when the traditional univariate methods are used.

The log-rank test (Equation 2) is a nonparametric method that is based on assigning a weight to the observations as a function of the significant difference between the expected and the observed distribution when the chi-square test was applied.

$$
\chi^{2}(\log -\operatorname{rank})=\frac{(O-E)^{2}}{\operatorname{VAR}(O-E)}
$$

Where: $\mathrm{O}=$ observed event; $\mathrm{E}=$ expected event; $\mathrm{VAR}=$ variance.

When analyzing survival data, two functions that are dependent on time are of particular interest: the survival function and the hazard function. The survival function $\mathrm{S}(\mathrm{t})$ is defined as the probability of surviving at least to time t. The hazard function $\mathrm{h}(\mathrm{t})$ is the conditional probability of dying at time $\mathrm{t}$ having survived to that time. The graph of $S(t)$ against $t$ is called the survival curve.

The Kaplan-Meier method can be used to estimate this curve from the observed survival times without the assumption of an underlying probability distribution. The method is based on the idea that the probability of surviving $t$ or more periods from entering the study is a product of the $\mathrm{k}$ observed survival rates for each period (i.e. the cumulative surviving proportion), given by Equation 3:

$$
\hat{S}=\prod_{t(i) \leq t} \frac{n i-d i}{n i}
$$

Where $n_{i}$ is the number of objects at risk at time $t_{(i)}$ (rank-ordered survival times: $\mathrm{t}_{(1)}<\mathrm{t}_{(2)}<\ldots<\mathrm{t}_{(\mathrm{m})}$ ), and $\mathrm{d}_{\mathrm{i}}$, is the observed number of events (Cox and Oakes, 1984).

For comparing the effect of different treatments (use of supernatants of $L$. acidophilus, $L$. rhamnosus and L. sake) on the survival times of the three tested pathogenic microorganisms, both parametric and nonparametric analyses were carried out. The log-rank test is used to test whether there is a difference between the survival times of different groups, but it does not allow other explanatory variables to be taken into account. Cox's proportional hazards model is analogous to a multiple regression model and enables the difference between survival times of particular groups to be tested while allowing for other factors. In this model, the response (dependent) variable is the 'hazard'. The hazard is the probability of dying (or experiencing the event in question) given that pathogenic microorganisms have survived up to a given point in time, or the risk of failure at that moment. In Cox's model no assumption is made about the probability distribution of the hazard. However, it is assumed that if the risk of dying at a particular point in time in one group is, e.g., twice that in the other group, then at any other time it will still be twice that in the other group. In other words, the hazard ratio does not depend on time.

The model can be obtained from the cumulative survival function $S(t)$ as written in Equation 4:

$$
H(t)=\ln S(t)
$$

The assumption that the proportional hazards stay constant along time can be inspected by looking at a graph showing the logarithm of the estimated cumulative hazard function. The assumption is equivalent to assuming that the difference between the logarithms of the hazards for the two treatments does not change with time, or equally that the difference between the logarithms of the cumulative hazard functions is constant.

\section{RESULTS}

In the case of neutralized supernatant, the inhibiting effect on the growth of pathogen microorganisms increased with increasing the dosage of L. acidophilus supernatant. Figure 1a represents the survival distribution curves for three independent neutralized Lactobacillus supernatants (L. acidophilus, L. rhamnosus and $L$. sake).

The lowest line is the distribution curve for the supernatant of $L$. acidophilus, indicating that the numbers of survivor pathogens were greater, at the same observation time, when the supernatants of $L$. rhamnosus and $L$. sake were employed. The $L$. rhamnosus and $L$. sake supernatants presented no significant difference on development of pathogens during the observation period $(24 \mathrm{~h})$, and the corresponding p-value was 0.791 . There were significant differences in pathogen inhibiting effect between $L$. acidophilus and L. rhamnosus and $L$. acidophilus and L. sake, the corresponding p-values were 0.0341 and 0.0168 , respectively (Table 1). 
Table 1 - Pairwise comparison of the different neutralized Lactobacillus supernatants with pathogenic microorganisms: $\chi^{2}$ and p-values.

\begin{tabular}{ccc}
\hline Lactobacillus & $\chi^{2}$ & p-value \\
\hline L. acidophilus $x$ L. rhamnosus & 1.43 & 0.0341 \\
L. rhamnosus $x$ L. sake & 0.02 & 0.7910 \\
L. acidophilus $x$ L. sake & 1.81 & 0.0168 \\
\hline
\end{tabular}

For the non-neutralized supernatants (Fig. 1a), it was observed that the antibacterial effect of $L$. acidophilus on the growth of $E$. coli, $L$. monocytogenes and $S$. aureus was more significant than those presented by L. rhamnosus and L. sake, as for the neutralized supernatants. For instance, in the case of $L$. acidophilus non-neutralized supernatants, only $8 \%$ of the pathogens survived after $20 \mathrm{~h}$ (probability $=0.08$ ), while a probability of $19 \%$ was obtained for $L$. rhamnosus and $L$. sake.

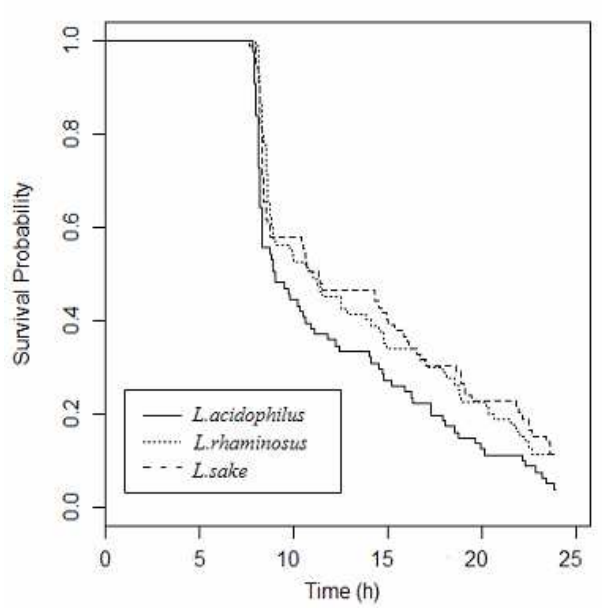

(a)
These effects may have been produced by a concomitant action of lactic acid low $\mathrm{pH}$ and the presence of bacteriocins or bacteriocins like substances (BLIS) in the supernatants.

The statistical test of the log-rank $((\mathrm{OE}) \wedge 2 / \mathrm{E})$ study pointed out significant differences between the three independent tests carried out using Lactobacillus supernatants (Table 2). When using the Kaplan-Meier method, the survival function for each independent supernatant was obtained, as shown in Figures 1a and 1b.

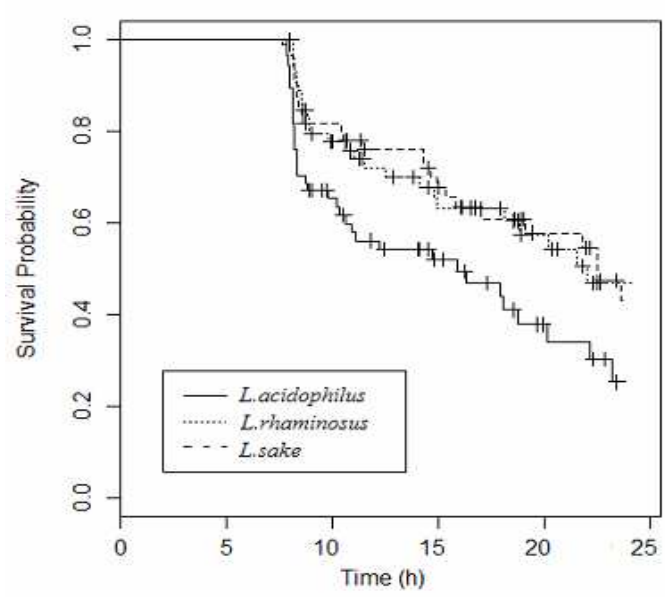

(b)

Figure1 - Survival distribution curves for three Lactobacillus species for neutralized supernatant (a) and non-neutralized supernatant (b). Evaluation of pathogenic failure was performed during $24 \mathrm{~h}(1.0=$ no pathogenic failure, $0.0=100 \%$ of pathogenic failure $)$.

Table 2 - Distribution of observed and expected events.

\begin{tabular}{|c|c|c|c|c|c|}
\hline Lactobacillus & $\mathbf{n}$ & Observed & Expected & $(\mathrm{O}-\mathrm{E})^{\wedge} 2 / \mathrm{E}^{1}$ & $(\mathrm{O}-\mathrm{E})^{\wedge} 2 / \mathrm{E}^{2}$ \\
\hline L. acidophilus & 180 & 122 & 104 & 2.991 & 6.94 \\
\hline L. rhamnosus & 180 & 97 & 104 & 0.515 & 1.20 \\
\hline L. sake & 180 & 94 & 104 & 2.023 & 2.38 \\
\hline
\end{tabular}

Note: ${ }^{1}$ : Test of log-rank, ${ }^{2}$ : Test of Peto's

Chi-square $=7.0$ on 2 degrees of freedom, $\mathrm{p}=0.038$ 
The log-rank statistical method, which under the hypothesis of equality of the survival curves should present a chi-square distribution with two degrees of freedom, resulted in a p-value of 0.038 , indicating significant differences in the antibacterial capacity of neutralized and nonneutralized Lactobacillus supernatants, being more visible in the case of L. acidophilus.

The use of neutralized supernatants showed, after $20 \mathrm{~h}$, a survival of $25 \%$ for L. acidophilus and around $40 \%$ for L. rhamnosus and L. sake Figure $1 \mathrm{~b}$, being the inhibitory effect of the supernatants probably caused by bacteriocins and lactate, excluding factors as low $\mathrm{pH}$ and/or production of lactic acid, since it was previously neutralized. Survival rates were higher than those observed in the experiments with non-neutralized supernatants. Figures $2 \mathrm{a}$ and $2 \mathrm{~b}$ present the curves corresponding to estimated cumulative risk for the three pathogenic microorganisms tested, and the relative effect of the neutralized and nonneutralized supernatants of $L$. acidophilus, $L$. rhamnosus and L. sake.

The risk ratio when $L$. acidophilus and the other two supernatants were evaluated was 1.81, meaning that the risk of occurrence of bacterial growth after $20 \mathrm{~h}$ is minor when using $L$. acidophilus as bioprotective starter (Fig. 2a e 2b).

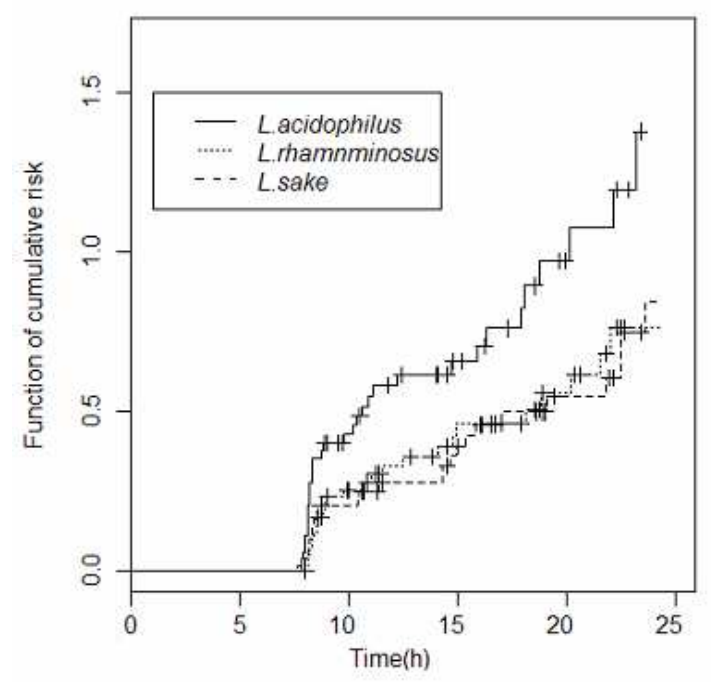

(a)

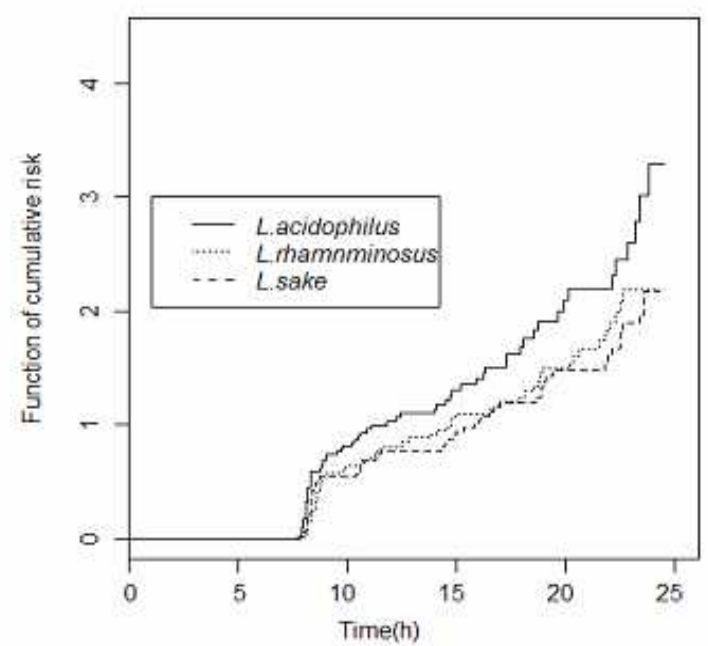

(b)

Figure 2 - Cumulative hazard function curves for three Lactobacillus microorganisms for neutralized supernatant (a) and non-neutralized supernatant (b). Evaluation of pathogenic failure was performed during $24 \mathrm{~h}$.

\section{DISCUSSION}

A statistical model using the survival approach was developed in order to evaluate the antagonistic effect of non-neutralized and neutralized lactic acid bacteria supernatants on three pathogenic bacteria, usual contaminants of meat and dairy products. The survival curves and the growth period previous to appearance of a failure may be used as a preliminary study for the evaluation of lactic acid bacteria starters. Besides, by using non- neutralized and neutralized supernatants, it should be possible to discriminate the effects of lactic acid and bacteriocins on growth of pathogenic microorganisms.

L. acidophilus supernatant presented a better performance than the other two in both cases, with neutralized as well as non-neutralized supernatants. The selection of starters as bioprotective agents is important to extend shelf life of fresh sausages and other fermented products. Further studies with real foods will 
determine the usefulness and application of this statistical approach. Schilliner and Lücke (1989) reported that $L$. monocytogenes was inhibited in minced meat by the presence of Lactobacillus sake $706 \mathrm{Lb}$, a producer of sakacin A. Several studies have reported the efficiency of lactic acid bacteria in sausage manufacture in order to control $L$. monocytogenes (Chikthimmah et al., 2001; Encinas et al., 1999).

Our results are in agreement with the inhibition of E. coli $\mathrm{O} 157: \mathrm{H} 7$ and $S$. aureus cultures by Lactobacillus acidophilus supernatant obtained by Rasmussen et al., (1993). Further work with a real model of sausage manufacture with starters could determine the validation of the presented statistical model.

\section{RESUMO}

Este trabalho apresenta um modelo estatístico de análise de sobrevivência para três bactérias patogénicas (Escherichia coli, Listeria monocytogenes e Staphylococcus aureus), quando tratados com sobrenadantes filtrados neutralizado e não neutralizado provenientes de culturas de Lactobacillus acidhophilus, Lactobacillus rhamnosus e Lactobacillus sake. A Análise de sobrevivência é um método utilizado para determinar o período de tempo a partir de uma fase inicial até a ocorrência de um determinado evento de interesse, como a morte ou a inibição de uma particular cultura, a fim de avaliar a eficácia potencial das referidas bactérias lácticas quando usadas como bioproteção em alimentos. Os dados experimentais foram tratados estatisticamente, seguindo a metodologia de Cox e Kaplan-Meier e foi possível fazer a seleção dos melhores fermentos láticos bioprotectivos, como uma ferramenta para avaliação preditiva, vida de prateleira e prevenção de eventuais riscos em Lingüiças frescas e outros produtos alimentares.

\section{REFERENCES}

Al-Nabulsi, A. A. and Holley, R. A. (2007), Effects on Escherichia coli O157:H7 and meat starter cultures of bovine lactoferrin in broth and microencapsulated lactoferrin in dry sausage batters. International Journal of Food Microbiology, 113, 84-91.
Baranyi, J. and Roberts, T. A. (1994), A dynamic approach to predicting bacterial growth in food. International Journal of Food Microbiology, 23, 277294.

Buchanan, R. L.; Whiting, R. C.; Damert, W. C. (1997), When is simple good enough: a comparison of the Gompertz, Baranyi, and three-phase linear models for fitting bacterial growth curves. Journal of Food Microbiology, 14, 313-326.

Caplice, E. and Fitzgerald, G. F. (1999), Food fermentations: role of microorganisms in food production and preservation. International Journal of Food Microbiology, 50, 131-149.

Carvalho, J.C; Oishi, B. O.; Soccol, C. R. (2005), Biopgments From Monascus: Strains Selection, Citrinin Production and Color Stability. Brazilian Archives of Biology and Technology, 48, 885-894.

Carvalho, M. S. (2005), Análise de sobrevida: teoria e aplicações em saúde. Editora Fio Cruz. 263-358.

Cocolin, L.; Rantsiou, K.; Iacumin, L.; Urso, R.; Cantoni, C.; Comi, G. (2004), Study of the ecology of fresh sausages and characterization of populations of lactic acid bactéria by molecular methods. Applied and Environmental Microbiology, 70, 1883-1894.

Chikthimmah, N.; Guyer, R. B.; Knabel, S. J. (2001), Validation of a 5-Log10 Reduction of Listeria monocytogenes following Simulated Commercial Processing of Lebanon Bologna in a model System. Journal of Food Protection, 64, 873-876.

Colossimo, E. A. and Giolo, S. R. (2006), Análise de sobrevivência aplicada. Editora Edgard Blücher, São Paulo.

Cox, D. R. and Oakes, D. (1984), Analysis of Survival Data. London, U.K.: Chapman and Hall, 201.

Crowley, J. and Breslow, N. (1994), Statistical analysis of survival data. Annual Review of Public Health, 5, 385-411.

Ederer, F.; Axtell, L. M.; Cutler, S. J. (1961), The relative survival rate: A statistical methodology. Journal of the National Cancer Institute, 6, 101- 121.

Encinas, J. P.; Sanz, J. J.; García-López, M. L.; Otero, A. (1999), Behaviour of Listeria spp. in naturally contaminated chorizo (Spanish fermented sausage). International Journal of Food Microbiology, 46, 167171.

Holzapfel, W. H. and Geisen, R. (1995), U. Biological preservation of foods with reference to protective cultures, bacteriocins and food-grade enzimes. International Journal of Food Microbiology, 24, 343-362.

Hugas, M.; Garriga, M.; Aymerich T.; Monfort J. M. (1993), Biochemical characterization of lactobacilli from dry fermented sausages. International Journal of Food Microbiology, 18, 107-113.

Hugas, M. (1998), Bacteriocinogenic lactic acid bacteria for biopreservation of meat and meat products. Meat Science, 49, 139-150. 
Hochberger, Y. (1998), A sharper Bonferroni procedure for multiple tests of significance. Biometrika, $\mathbf{7 5}$, 800-802.

Jarvis, B. (1989), Statistical aspects of the microbiological analysis of foods. Elsevier Science Publishers, Amsterdam, The Netherlands.

Kaplan E. L. and Meier P. (1958), Nonparametric estimation from incomplete observations. Journal of the American Statistical Association, 53, 457-481.

Klaenhammer, T. R. (2001), Probiotics and prebiotics. In: Doyle, M. P.; Beuchat, L. R.; Montville, T. Journal of Food Microbiology: fundamentals and frontiers. 2.ed. Washington: ASM, 797-811.

Klaenhammer, T. R. (1993), Genetics of bacteriocins produced by lactic acid bacteria. FEMS Microbialogy, 12, 39-86.

Kleinbaum, D. G. (1995), Survival Analysis: A SelfLearning Text. New York: Springer.

Koutsoumanis, K. P. and Sofos, J. N. (2005), Effect of inoculum size on the combined temperature, $\mathrm{pH}$ and aw limits for growth of Listeria monocytogenes. International Journal of Food Microbiology, 104, 8391.

Lee, E. T. (1992), Statistical Methods for Survival Data Analysis. 2.ed. New York: John Wiley and Sons.

Lücke, F. K. (2000), Utilization of microbes to process and preserve meat. Meat Science, 56, 105-115.

Man, J. C.; Rogosa, M.; Sharpe, M. E. (1961), A medium for the cultivation of Lactobacilli. Journal of Applied Bacteriology, 23, 130-135.

Mantel N. (1966), Evaluation of Survival data and two new rank order statistics arising in its consideration. Cancer Chemotherapy Reports, 50, 163-170.

Nightingale, K. K., Thippareddi, H., Phebus, R. K., Marsden, J. L., Nutsch, A.L., 2006. Validation of Traditional Italian-Style Salami Manufacturing Process for Control of Salmonella and Listeria monocytogenes. Journal of Food Protection, 69, 794800.

Nissen, H. and Holck, A. (1998), Survival of Escherichia coli o157:H7, Listeria monocytogenes and Salmonella kentuckyin Norwegian fermented, dry sausage. International Journal of Food Microbiology, 15, 273-279.

Parada, J. L.; Caron, C.R.; Medeiros, A. B. P.; Soccol, C. R. (2007), Bacteriocins from lactic acid bacteria:purification properties and use as biopreservatives. Brazilian Archives of Biology and Technology, 50, 521-542.

Peto, R.; Pike, M. C.; Armitage, P.; Breslow, N. E.; Cox, D. R.; Howard, S. V.; Mantel, N.; McPherson, K.; Peto, J.; Smith, P.G. (1977), Design and analysis of randomized clinical trials requiring prolonged observation of each patient. II. Analysis and examples. British Journal of Cancer, 35, 1-39.
Prado, F.; Parada, J.; Pandey, A.; Soccol, C. (2008), Trends in non-dairy probiotic beverages. Food Research International, 41, 111-123.

Ramadas, N. V.; Singh, S. K.; Soccol, C. R.; Pandey, A. (2009), Polyhydroxybutyrate production using agroindustrial residues as substrate by Bacillus sphaericus NCIM 5149. Brazilian Archives of Biology and Technology, 52, 17-23.

Rasmussen, M. A.; Cray, W. C.; Casey, T. A. (1993), Rumen contents as a reservoir of enterohemorraghic Escherichia coli. FEMS Microbiology-Letters, 114, 79-84.

Samelis, J.; Metaxopoulos, J.; Vlassi, M.; Pappa, A. (1998), Stability and safety of traditional Greek salami - a microbiological ecology study. International Journal of Food Microbiology, 44, 6982.

Sanada, C. T. N.; Karp, S. G.; Spier, M. R.; Portella, A. C.; Gouvêa, P. M.; Yamaguishi, C. T.; Vandenberghe, L. P. S.; Pandey, A.; Soccol, C. R. (2009), Utilization of soybean vinasse for $\alpha$ galactosidase production. Food Research International, 42, 487-496.

Shah, N. P. (2000), Probiotic bacteria: Selective enumeration and survival in dairy foods. Journal Dairy Science, 83, 894-907.

Schillinger, U. and Lücke, F. K. (1989), Antibacterial activity of Lactobacillus sake isolated from meat. Applied and Environmental Microbiology, 55, 19011906.

Stiles, M. E. (1996), Biopreservation by lactic acid bacteria. Antonie Leeuwenhoek, 70, 331-345.

Tagg, J. R.; Dajani, A. S.; Wannamaker, L. W. (1976), Bacteriocins of gram-positive bacteria. Bacteriology, 40, $722-756$.

Yamagushi, C. T.; Sanada, C. T. N.; Gouvêa, P. M.; Pandey, A.; Woiciechowski A. L.; Parada, J. L.; Soccol, C. R. (2009), Biotechnologycal process for producing black bean slurry without stachyose. Food Research International, 42, 425-429.

Thévenot, D.; Delignette-Muller, M. L.; Christieans, S.; Vernozy-Rozand, C. (2005), Fate of Listeria monocytogenes in experimentally contaminated French sausages. International Journal of Food Microbiology, 101, 189-200.

Työppönen, S.; Markkula, A.; Petäjä, E.; Suihko, M. L.; Mattila-Sandholm, T. (2003), Survival of Listeria monocytogenes in North European type dry sausages fermented by bioprotective meat starter cultures. Food Control, 14, 181-185.

Vermeiren, L.; Devlieghere, F.; Debevere, J. (2004), Evaluation of meat born lactic acid bacteria as protective cultures for the biopreservation of cooked meat products. International Journal of Food Microbiology, 96,149-164. 